Writing IN THE AIR 



\title{
ANTONIO CORNEJO POLAR
}

\section{Writing IN THE AIR \\ Heterogeneity and the \\ Persistence of Oral Tradition \\ in Andean Literatures}

\author{
Translated by \\ LYNDA J. JENTSCH
}

Foreword by

JEAN FRANCO 
(C) 2013 Duke University Press

All rights reserved

Printed in the United States of America on acid-free paper $\infty$ Designed by Heather Hensley

Typeset in Whitman by Tseng Information Systems, Inc.

Library of Congress Cataloging-in-Publication Data

Cornejo Polar, Antonio.

[Escribir en el aire. English]

Writing in the air : heterogeneity and the persistence of oral tradition in Andean literatures / Antonio Cornejo Polar ; translated by Lynda J. Jentsch ; with a foreword by Jean Franco.

pages $\mathrm{cm}$

Includes bibliographical references and index.

ISBN 978-o-8223-5417-8 (cloth : alk. paper)

ISBN 978-o-8223-5432-1 (pbk. : alk. paper)

1. Peruvian literature-History and criticism. 2. Bolivian literature-History and criticism. 3. Ecuadorian literatureHistory and criticism. 4. Literature and society-Andes Region. 5. Culture in literature. I. Title.

PQ7551.C6713 2013

$860.9^{\prime} 985-\mathrm{dc} 23 \quad 2013003134$ 